Session 15470

\title{
Senior Project Presentations
}

\author{
Beverly J. Hunter, Stanley J. Pisarski, Kathy C. Bearden \\ University of Pittsburgh at Johnstown
}

\begin{abstract}
The current paper describes the Senior Project Proposal and Senior Project classes that comprise the capstone design sequence for Engineering Technology students at the University of Pittsburgh at Johnstown. This design sequence is required for all Civil, Electrical, and Mechanical Engineering Technology students. The paper discusses the investigative work required prior to undertaking a project design, the types of projects that are undertaken, the sources of project ideas and the magnitude of the projects. Descriptions of both courses for all three majors are provided.
\end{abstract}

\section{Course Organization}

The Civil, Electrical and Mechanical Engineering Technology programs at the University of Pittsburgh at Johnstown require a capstone design sequence where students prepare a project proposal and then complete a senior project design. This two-term course sequence is taken during the last two terms before graduation.

The first portion of the capstone course is Senior Project Proposal. Civil Engineering Technology (CET) students form groups, formulate the initial idea for the project and write a preliminary proposal. The entire CET faculty reads the preliminary proposals to determine if the ideas have merit and to suggest revisions. Students continue to rewrite the preliminary proposal until it is accepted and then begin work on a final proposal. The final proposal also goes through an iterative process. It is eventually used as an outline for the senior project work that follows in the next term. Student groups make five-minute presentations before the sophomore, junior and senior CET students at the end of the term to describe their proposed projects. The second portion of the capstone course is the Senior Project course. Students perform design calculations and produce written reports and drawings to document their work. Each week during the term students meet with their advisors to discuss progress and problems. At the end of the term, student groups make presentations before students, faculty, project sponsors and interested members of the local community.

The Senior Project Proposal course taken by Electrical Engineering Technology (EET) students has undergone major revisions in recent years to modify the course sequence format. These modifications were instituted to increase the probability for successful senior project completion. In the proposal phase the students draft a proposal for their senior project that is circulated among the EET faculty for approval. Functional specifications, block diagram design, time schedules and task division among the project members quickly follow the proposal and the term 
commences with the final paper design of the proposed project. Each phase of the project is communicated to other EET students and faculty through oral presentations during weekly EET seminars. This provides the sophomores and juniors with an opportunity to observe the process that is used during the proposal/design phases and allows them to participate, comment, and share their ideas with the project team members about the proposed projects.

The break between terms is used by the EET students to order parts for the assembly/testing phase that occurs during the second term. This buffer allows time to procure the parts so that start up delays during the initial weeks of the second term are minimized and assembly can begin immediately. During the second term the students enroll in the Senior Project course. The students transform their paper designs into intellectual software and physical hardware devices. Test data is produced and recorded as the software and hardware are debugged. Design deficiencies are corrected if possible and documentation is produced. Final schematic drawings and user manuals are created and the results of the project are orally presented to family, faculty, staff, students, project sponsors, and friends during the final EET seminar for the term.

Mechanical Engineering Technology (MET) Department students prepare a senior project proposal that is defended at the end of the first semester. The proposal must include a detailed statement of work, a cost estimate and a timeline. As part of the proposal effort, students are encouraged to initiate project activities to demonstrate feasibility and to aid them in developing reasonable goals and objectives. The bulk of the project activities are performed during the second semester and includes an intermediate design review, scheduled midway through the semester. This midterm deadline encourages students to keep their activities moving along in a timely fashion. As with the proposal defense, the review is performed in front of the other project teams and the department faculty. Use of a wide audience gives the students an opportunity to receive feedback from diverse viewpoints including their peers. The final defense occurs at the end of the semester. Students are required to write a detailed report and give a formal presentation to department faculty, students, sponsors and family. Juniors are encouraged to attend all presentations so that they can get a better idea of what will be expected of them. Where practical, support of senior project activities is embedded in senior level courses. For example, those that take Finite Element Analysis are required to do a final project for the course and are encouraged to do a project related to their senior project activities.

\section{Recent Civil Engineering Technology Projects}

Many of the Civil Engineering Technology department senior project ideas result from interaction with community or governmental groups. Two projects completed within the past two years entitled "Foustwell Access Project for the Stonycreek Whitewater Park" and "Design of a Maintenance Facility and Access Road for Whitaker Roads Corporation" are examples of such interaction. Students select projects that incorporate personal interests and offer design challenges.

The Stonycreek Whitewater Park is in the planning stage. A local canoe club, the planning commission and the local government are all interested in developing a section of the Stonycreek River for recreational and tourism purposes. A member of the planning commission brought this project to the attention of the CET Department. One of the students involved with this project is

\footnotetext{
"Proceedings of the 2001 American Society for Engineering Education Annual Conference \& Exposition Copyright @ 2001, American Society for Engineering Education”
} 
a paddler that is active in the canoe club. His goal was to design an area that would be easy to use and attractive. The 7.5 acre Foustwell site sits at the beginning of a six-mile stretch of continuous whitewater through a 500 foot deep canyon. The whitewater stretch is considered to be one of the premier runs in the eastern United States. The area selected for the access project was located near a highway bridge and adjacent to a railroad. Students generally attempt to select projects that utilize a variety of topics from upper level courses. This project included surveying, site layout, geotechnical analysis, structural analysis, hydrology, hydraulics and environmental concerns. A topographic survey was completed to locate the existing roadways, railroad facilities, and utilities and to define the topography of the area. Additionally, the area was examined to delineate wetlands and the 100-year floodplain elevation. Soil analyses were performed to determine the existing soil conditions and the bearing capacity for structures. Students conducted several tests including moisture content, a sieve analysis, a hydrometer analysis, liquid and plastic limits and a pocket penetrometer test. A structure to be used as a restroom and changing facility as well as an educational center and lab was designed for the site. The students designed the trusses, the masonry walls, the footing and the floor slab. Students researched local ordinances regarding building restrictions in the floodplain area and considered the need for handicap accessibility. An access road, parking lot and two trails down to the river were also part of the project. A cost analysis was conducted.

The Whitaker Roads Corporation has an office building and asphalt plant in one location and a maintenance facility in another. The office building and maintenance facility are no longer adequate. The Corporation decided that the company would be more efficient if all of the operations would be relocated to the asphalt plant site and a new combination office building and maintenance facility would be built there. One of the students involved in this team project was an employee of Whitaker Roads and was aware of the shortcomings of the existing arrangement. The main components of this project were a road design, building design, hydrologic study and construction scheduling. The roadway design included a road realignment and pavement design. Safety issues had to be addressed because an increase in the amount of traffic at the site would occur as a result of the relocation of the maintenance facility. Pennsylvania Department of Transportation design criteria were used to determine the pavement design. A parking area and truck turning area were also designed. The BOCA National Building Code was used in the design of the office building/maintenance facility. All loads were calculated using the code as the basis. The facility will be located in a case study area for snow loads, so local conditions were investigated and incorporated into the design. The truck loads expected to be experienced at the facility were determined and used to calculate the floor loads used to design the reinforced concrete floor. Special loading conditions resulting from the way the building is to be utilized were also incorporated into the load calculations. A hydrologic study of the site was conducted to determine the amount of runoff that could be expected. The students investigated the possibility of using storm runoff water as plant process water. The result of the calculations showed that the volume of water was insufficient to meet the plant need. Students also prepared a schedule to detail the sequencing of the construction.

\section{Recent Electrical Engineering Technology Projects}

The University of Pittsburgh at Johnstown is located approximately seventy miles east of Pittsburgh, Pennsylvania. This places UPJ geographically distant from local heavy industry.

\footnotetext{
"Proceedings of the 2001 American Society for Engineering Education Annual Conference \& Exposition Copyright (C) 2001, American Society for Engineering Education”
} 
Thus, ideas for the EET senior projects come from a variety of sources. These include the students themselves, companies the students intern with during the school year and summer months, faculty members across campus, and other divisions within the university. Students are encouraged to obtain corporate sponsorship to help identify the details in the project description as well as help by monetarily financing the project. Approximately $10 \%$ of the projects are corporate sponsored while the remaining projects end up being individually sponsored by the students.

Two recently completed projects entitled "Variable Speed Drive Remote Controller" and "Electrical Loading System for Power Supply Burn-in" were sponsored by local corporate and government agencies. The "Variable Speed Drive Remote Controller" project was sponsored by the Naval Surface Welfare Center and the "Electrical Loading System for Power Supply Burnin" was financed by K. H. Controls Incorporated. One member from each project group worked as an intern with the sponsor prior to proposing their senior project. The sponsoring groups saw the projects as an important learning experience for the team members.

The "Variable Speed Drive Remote Controller" serves as a remote interface to a variable speed motor drive on the power generation equipment on board naval surface vessels. Remote motor drive control and monitoring was currently nonexistent and local control was awkward and difficult. A variable speed motor control drive was loaned to the design team by the Naval Surface Warfare Center to allow the students to complete the design, testing and documentation of their senior project prototype. The interface utilized menu driven software and hardware to control and monitor the variable speed motor drive parameters. Motor commands were entered through keypad controls and motor drive status was indicated by multi-line liquid crystal displays while warning indicators utilized light emitting diode indicators. All electronic circuitry was inserted on custom-made printed circuit boards to increase circuit reliability.

The "Electronic Loading System for Power Supply Burn-in" functioned as a variable dc current sink for power supply burn-in at K. H. Controls Inc. K.H. Controls produces several different rated switching power supplies. Testing involves providing a different load current to each type of supply during the burn-in phase of product testing. Resistive loads were previously used for testing but offer imprecise load current control and no opportunity for voltage and current parameter monitoring during the burn-in cycle. The senior project device utilized power MOSFET transistors to control the flow of power from the supplies and also afforded monitoring and data acquisition capabilities for more acceptable power supply testing. Remote interfacing to a personal computer allowed parameter data to be saved to a computer hard drive for mass data storage during the burn-in phase of testing. Parametric data was entered via a keypad and local readback was displayed with multi-line liquid crystal display modules.

Final reports for each project consist of block diagrams, final electrical schematics, test data, user manual information, parts lists, a detailed operational description of the hardware, and detailed software documentation including flowcharts and fully-commented microcontroller source code. In addition, oral presentation material including power point slides becomes part of the final documentation. Objectives for completing the senior project capstone course include: increasing team building and troubleshooting skills, instilling time management and design procedure techniques, and improving oral and written communication skills.

\footnotetext{
"Proceedings of the 2001 American Society for Engineering Education Annual Conference \& Exposition
} Copyright $\odot$ 2001, American Society for Engineering Education” 


\section{Recent Mechanical Engineering Technology Projects}

The Mechanical Engineering Technology projects generally fall into three main categories: industrial partnerships, individual research, and projects used to enter national design contests such as those sponsored by the Society of Automotive Engineers. Individual or team research projects are probably the most tenuous in regard to achieving a successful and useful end. Without an industrial partner or the goal of participating in a national contest, it is hard for some students to remain on track and focused. Although each team has a professor to provide guidance, exceptional motivation on the part of the students is critical for success. Previous projects included installation of a dynamometer purchased by the Engineering Technology Division, design of a minor losses flow measurement system, and design of a heating and ventilation system for a private residence. What sometimes happens during these projects is that initial goals are modified as the students run out of time to complete the work they proposed. For example, the minor losses project was scaled back from design, installation, and testing to design alone.

National contests such as the Mini-Baja or the Formal One racecars have proven to be very exciting for the students and the hands-on experience in designing and building the cars is invaluable. However, these projects can be very expensive and often the inability of the students to obtain proper funding has resulted in limited success. Furthermore, the relatively short time period often results in a final product that is assembled with little real engineering.

Industrial partnerships usually result in superior senior projects since they are based on real world needs. For these projects, students work with an industrial partner to solve a specific problem. They greatly benefit from the mentoring they receive while working on the project, they are exposed to a different working environment, their job skills are enhanced, and there can be the added incentive of potential employment after graduation. The downside of industrial projects is that the company may halt work on the project for reasons beyond the student's control and leave the student in a situation where they have to modify the project to a version that they can successfully complete on their own. Students have worked with companies that perform engineering design, manufacturing, and research. The companies range in size from small family engineering firms to large government contractors.

One recent project validated computer-modeling techniques for simulating metal forming operations. As part of the project, the student developed computer based models of the rolling process, then obtained test data and used the data to validate the model results. In another manufacturing-related project, the students worked with a small manufacturing company to design and build a control system for a chocolate chip processing facility. On a simpler scale, students worked with a local company that builds modular buildings to design a lifting rig to assist with moving building panels about the site. The students developed a finite element model of the lift rig and attempted to validate the model using test results from a scale model of the rig. Analysis of the rig required the students to consider all the different normal and off-normal loads that the lift rig might incur during use and to think beyond the simple static loads from the weight of the panel structure. One of the more difficult challenges for the students was the requirement for easy assembly of the test rig. To meet this requirement, the students needed to minimize the number of bolted joints yet maintain the ability to break the lifting rig down for

\footnotetext{
"Proceedings of the 2001 American Society for Engineering Education Annual Conference \& Exposition Copyright (C) 2001, American Society for Engineering Education”
} 
easy transport. In all of these projects, the students are primarily focused on completing the project, compiling the final report and surviving the oral defense. However, the most important and rewarding aspect for the students is what they have learned by working through the project, whether or not the project was a resounding success.

\section{Conclusions}

The Senior Project Proposal and Senior Project capstone design courses have provided Civil, Electrical and Mechanical Engineering Technology students with an opportunity to incorporate knowledge and skills into a professional, high quality end product. The projects undertaken by the students have proven to be technically challenging and a means of documenting the capabilities of senior students.

Bibliography

1. CET 1195 Senior Project Proposal student work Fall 1999, team of 3

2. CET 1199 Senior Project student work, Spring 2000, team of 3

3. CET 1195 Senior Project Proposal student work Fall 1999, team of 4

4. CET 1199 Senior Project student work, Spring 2000, team of 4

5. EET 1195 Senior Project Proposal student work Fall 1997, team of 2

6. EET 1199 Senior Project student work Spring 1998, team of 2

7. EET 1195 Senior Project Proposal student work Fall 1999, team of 2

8. EET 1199 Senior Project student work Spring 2000, team of 2

9. MET 1195 Senior Project Proposal student work Fall 1999, team of 3

10. MET 1199 Senior Project student work Spring 2000, team of 3

11. MET 1195 Senior Project Proposal student work Fall 1998, team of 2

12. MET 1199 Senior Project student work Sprig 1999, team of 2

13. MET 1195 Senior Project Proposal student work Fall 2000, team of 1

14. MET 1195 Senior Project Proposal student work Fall 1997, team of 3

15. MET 1199 Senior Project student work Spring 1998, team of 3

16. Pisarski, S., "EET Senior Project Proposal Guidelines," EET 1195 Course Syllabus, University of Pittsburgh at Johnstown, 1999.

17. Pisarski, S., "EET Senior Project Guidelines," EET 1199 Course Syllabus, University of Pittsburgh at Johnstown, 2001.

18. Hunter, B., "CET Senior Project Proposal Guidelines," CET 1195 Course Syllabus, University of Pittsburgh at Johnstown, 2001.

19. Hunter, B., "CET Senior Project Guidelines," CET 1199 Course Syllabus, University of Pittsburgh at Johnstown, 2001.

20. Klavuhn, J., "MET Senior Project Proposal Guidelines," MET 1195 Course Syllabus, University of Pittsburgh at Johnstown, 1996.

21. Klavuhn, J., "MET Senior Project Guidelines," MET 1199 Course Syllabus, University of Pittsburgh at Johnstown, 1996.

22. Hales, J. and Pisarski, S., "Evolution of a Capstone Course: A Twenty-Year Persepective", 1998 FIE Proceedings, Tempe, AZ.

23. Peterson, J. N., "Experiences in Capstone Design Projects: Partnerships with Industrial Sponsors", 2000 ASEE Annual Conference Proceedings, St. Louis, MO.

24. Wipplinger, L., "Group Projects", 2000 ASEE Annual Conference Proceedings, St. Louis, MO.

25. Pike, M., "Capstone Design Courses: A Comparison of Course Formats", 2000 ASEE Annual Conference Proceedings, St. Louis, MO.

"Proceedings of the 2001 American Society for Engineering Education Annual Conference \& Exposition Copyright $\odot$ 2001, American Society for Engineering Education” 
BEVERLY J. HUNTER, P.E.

Beverly J. Hunter is currently an Associate Professor and Department Head of Civil Engineering Technology at the University of Pittsburgh at Johnstown. She received her B.S. in Civil Engineering Technology from the University of Pittsburgh at Johnstown and her M.S. in Civil Engineering from the University of Pittsburgh.

STANLEY J. PISARSKI, P.E.

Stanley J. Pisarski is currently an Instructor of Electrical Engineering Technology at the University of Pittsburgh at Johnstown. He received his B. S. in Electrical Engineering Technology from the University of Pittsburgh at Johnstown and his M. S. in Manufacturing Systems Engineering from the University of Pittsburgh.

KATHY C. BEARDEN

Kathy C. Bearden is currently an Assistant Professor of Mechanical Engineering Technology at the University of Pittsburgh at Johnstown. She received her B.S. and M.S. in Mechanical Engineering from Virginia Polytechnic Institute and State University. 